\title{
先端拡底杭基礎上のケーソン岸壁の地震時挙動に関する一考察 Seismic Behavior of a Caisson Type Quay Wall Resting on Pile Foundation with Expanded Base
}

\author{
高谷 富也*・前野 賀彦**.児玉 洋介***
}

Tomiya Takatani, Yoshihiko Maeno and Hirosuke Kodama

\begin{abstract}
Dynamic behavior of a caisson type quay wall resting on pile foundation with expanded base was numerically evaluated by a liquefaction analysis based on effective stress model during 1995 Hyogo-ken Nanbu Earthquake. The effective stress model used for the liquefaction analysis during earthquake motion was a strain space multiple mechanism model. The deformation during the earthquake ground motion induced due to pore water pressure in the soil behind the caisson quay wall. Though the displacement response of the caisson quay wall with pile foundation was smaller than that of the caisson without pile foundation, the deformation was mainly induced by the increase of pore water pressure.
\end{abstract}

Key words: Caisson type quay wall, deformation, pile foundation, liquefaction

\section{1.はじめに}

兵庫県南部地震による阪神地区の海岸構造物・港湾施設 の被害については、被災後の調査検討を経て多く報告され ている（例えば、運輸省港湾局、1995）。外洋波浪に対す る耐波設計を行っていない港湾施設が地震により被災する ことは十分予想されるところである。しかしながら、頻度 の少ない地震に対する耐震設計を全ての港湾施設に行うこ とは経済的条件から非現実的である。災害復旧や経済活動 に重要な役割を有する港湾施設に対しては集中的な投資は 必要であり論を待たないところであるが、その際にも経済 的合理性を有する臫震設計が求められる。また、万が一の 被災に対しても復旧・修復が容易な構造形式についても十 分検討されるべきである。多くの被災報告の中に、短杭で はあるが先端に拡大球根を有する杭が耐震性を発揮したと される事例や杭を用いた係船岸や栈橋が周辺における他の 形式の構造物に比べて比較的被害が軽度であったとの報告 も認められた。地盤条件や施工状態など他の要因も考えら れることから、これらの報告を先端拡底杭の耐震性を肯定 するものと即断することは危険であるが、検討する必要が あると考えられる。このような背景から、前野ら（1997） は、まず先端拡底杭をケーソン基礎に配した構造を考え、 外洋波浪に対して十分な耐波性能を有する場合には耐震性 を満足する場合が多いとの経験に基づき、その波浪に対す る基礎地盤の応答特性を検討した。それによれば、先端拡 底杭を用いることにより海底地盤表面付近における繰り返 し波浪により生じる過剩間隙水圧の消散に伴うケーソン前 面法先部の沈下やケーソン直下における沈下による空洞の 発生が抑制されることが確認できた。

\footnotetext{
* 正会員 舞鶴工業高等専門学校 建設システム工学科 于625-8511 京都府舞鶴市白屋 234 番地 ** 正会員 日本大学短期大学部 建設学科 *** 正会員 児玉コンクリート（株）
}

このような状況を考虑して、本研究では実際に兵庫県南 部地震において観測された沿岸部での加速度記録を入力波 形として、従来より軟弱地盤の沈下予測に用いられている 弾塑性有限要素法を用いた先端拡底杭を基礎に有するケー ソン岸壁 (係船岸) の地震応答解析を行い、ケーソン構造 物基礎への先端拡底杭の適用性の検討を行った。

\section{2. 解析方法}

本研究では、軟弱地盤における先端拡底杭基礎上に設置 されたケーソン式倸船岸の地震時応答特性の検討を有効応 力に基づく液状化解析法を用いて行う（Iai,S. et al.,1992）。 軟弱地盤に群杭基礎を設け、その上にケーソン式係船岸の 設置を想定するが、係船岸底面を杭頭に直接載せた場合に は杭の沈下によりケーソン壁体底面に空洞が生じる可能性 があることから、施工に際しては杭頭を捨て石層で覆った 後に壁体を設置するように『港湾の施設の技術上の基淮・ 同解説』（1985）に指示されている。そこで、本研究では、 被災したケーソン岸壁を対象とし、通常の直杭基礎に直接 接続している場合と杭頭を捨て石層で覆いケーソンとの接 続を行わない場合について応答解析を行い、両者の比較・ 検討を行う。また、これらの結果を踏まえて、先端拡底杭 基礎上のケーソン岸壁の地震時応答特性について調べる。 なお、杭基礎上に設置されるケーソン式係船岸モデルに作 用させる加速度波形は、兵庫県南部地震時に記録されたも のを用いる。

図ー 1 は、神戸ポートアイランドにおける解析対象とし たケーソン岸壁（PC-1）の位置および解析に用いた加速 度波形が測定された地震計の設置場所を示したものである。 また、ケーソン岸壁（PC-1）の標準断面を図ー2に示す。 なお、このケーソン岸壁の地震後の変形量は岸壁上部工天 端が海側水平方向に $2.6 \sim 3.2 \mathrm{~m}$ 、鉛直方向に $0.8 \sim 1.0 \mathrm{~m}$ の 沈下となっている（稲森ら、1997）。また、図ー3には図 


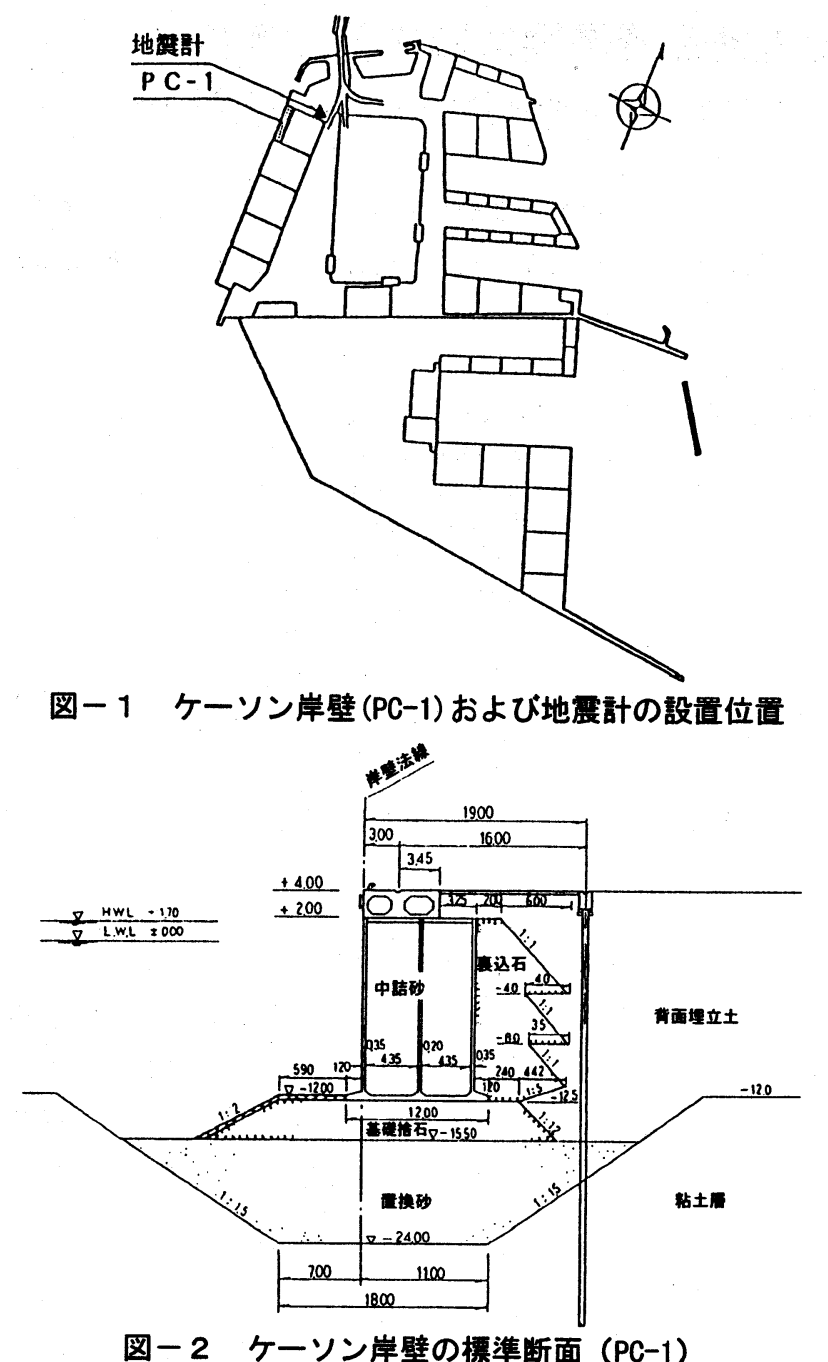

ついては NS 成分のものを用いて、非排水条件下で時刻歴 応答解析を行った。

\section{3. 解析結果とその考察}

本研究では、ケーソン岸壁を直杭基礎に直接接続してい る場合（Type A)、杭頭を捨て石層で覆いケーソンとの接 続を行わない場合（Type B) および図ー2に見られるよ うに置換砂の上に捨て石マウンドを設置した通常のケーソ ン岸壁の場合 (Type C) の 3 つの場合について地震時応 答解析を行い、図一4に見られるいくつかの節点における
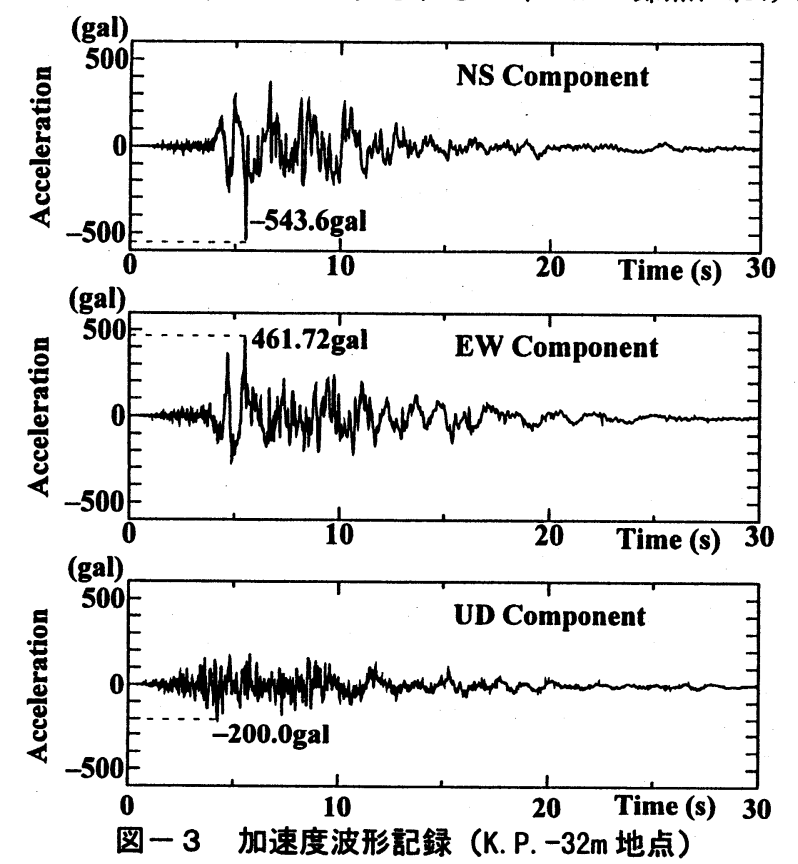

- 1 に示すポートアイランドの K.P.-32m における地震計で実測 された加速度波形を示しておく。 この加速度波形を基にして、森 田（1997）および稲垣・井合 （1997）らはこのケーソン岸壁 を対象とした地震時変形挙動解 析を行い、解析結果と被災資料 との比較・検討を行っている。

本研究で用いたケーソン岸壁 周辺地盤の FEM 解析メッシュ 図を图ー4に示す。なお、ケー

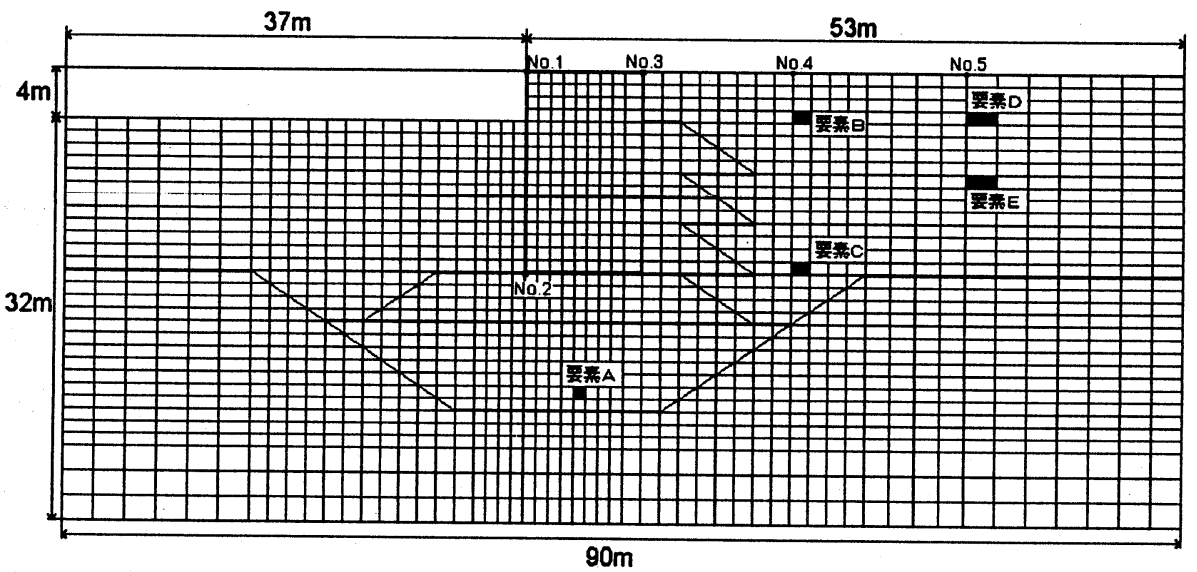

図一４FEM解析メッシュ図 ソンと周辺地盤との間にはジョイント要素を設けている。 また、同図中には地震時の時刻歴応答評価を行ういくつか の節点および要素を明示しておく。

解析対象断面は、ケーソン岸壁法線より海側 $37 \mathrm{~m}$ 、陸 側 $41.5 \mathrm{~m}$ 、地表面（K.P. $+4 \mathrm{~m}$ )、海面より K.P. $32 \mathrm{~m}$ の範 囲となっており、図一2に示すケーソン岸壁の標淮断面を 基にしてメッシュ化したのもである。また、入力地震動と して、図一ろに示す K.P.-32m における観測波形の水平動 および上下動成分の主要動を含む 30 秒間を用い、FEM 解析メッシュの最下層に入力した。なお、水平動動成分に

变位および要素の過剩間隙水圧比について調べる。

図一5は、Type A、Type B および Type Cに対する地 震応答解析結果の残留変形量を示したものである。この図 から明らかなように、ケーソン岸壁を杭基礎に直接接続し た Type A の場合におけるケーソン岸壁天端の変位量は、 Type B および Type C の場合に比べて小さくなっており、 杭基礎の存在によりケーソン岸壁の海側への滑り出しおよ び傾斜が抑制されていることがわかる。一方、杭基礎を有 しない Type C の場合には、岸壁背面の埋め立て地盤の液 状化の影響を受けて、捨て石マウンド内部への沈下および 
海側への滑り出しおよび傾斜 が顕著なものとなっている。 なお、杭頭を捨て石層で覆い ケーソンとの接続を行わない Type B の場合については、捨 て石マウンド直下に杭基礎が 存在するため、置換砂の変形 および捨て石マウンドの不等 沈下を抑制する効果を有して いるため、杭基礎を有しない Type C の場合に比べて上述の 傾向は小さなものとなってい ることがわかる。

表一 1 は図ー 4 に示す節点 No.1 5 の 30 秒後の最終変 位量を示したものである。ま た、図ー6はこれら5つの節 点変位の時刻歷応答を Type A、 Type B および Type Cについ て図示したものである。表一 1 および图ー6からも明らか なように、杭基礎を有しない Type C の場合におけるケーソ ン岸壁天端の節点 No.1 の変 位量が最も大きくなっている。 また、いずれの節点において も、水平変位量は捨て石マウ ンド直下に杭基礎を設置した Type B と杭基礎を有しない Type C がほぼ同じものとなっ ており、杭基礎と直接接続し た Type A の場合の水平変位 は Type B と Type C に比べて小さな值となって いることがわかる。したがって、捨て石マウンド 直下での杭基礎の存在が水平方向変位に及ぼす影 響は小さいことを示唆しているものと考えられる。 また、ケーソン岸壁から離れるにつれてそれぞれ のタイプの違いによる水平変位への影響は小さく なっている。

一方、杭基礎と直接接続した Type A の場合におけるケ ーソン岸壁の沈下は Type B およびType C に比べてかな り小さくなっており、杭基礎のケーソン岸壁との接続の効 果はケーソンの沈下抑制に関して有効であることがわかる。 また、ケーソン岸壁背面における No.4 および No.5 の変 位については、杭基礎の存在により埋め立て地盤の液状化 による側方流動を抑制する効果を有していることがわかる。 したがって、ケーソン岸壁直下に杭基礎を設置する Type A の場合は、ケーソン岸壁の海側への滑り出しおよび傾斜量 をかなり抑制することがわかる。また、捨て石マウンド

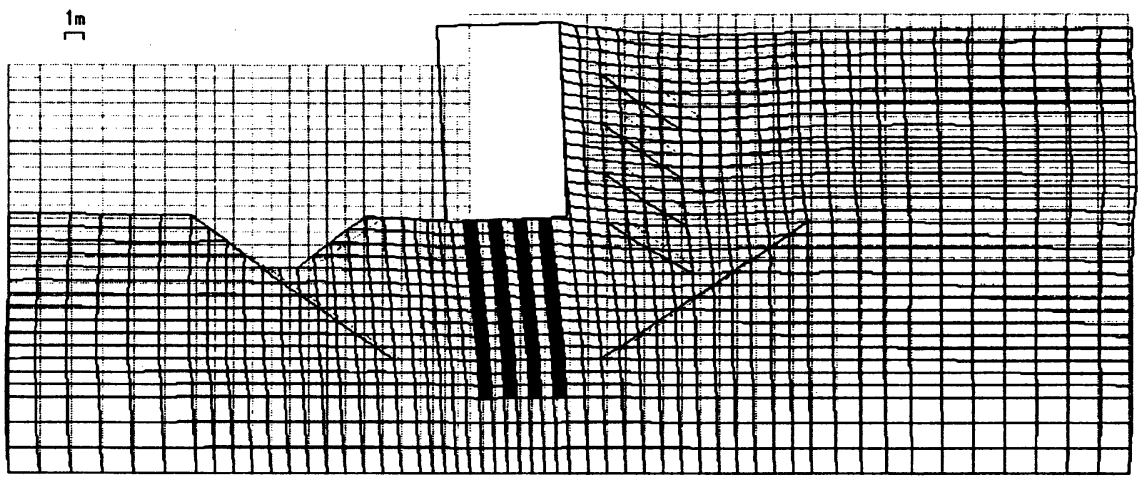

(a) Type A

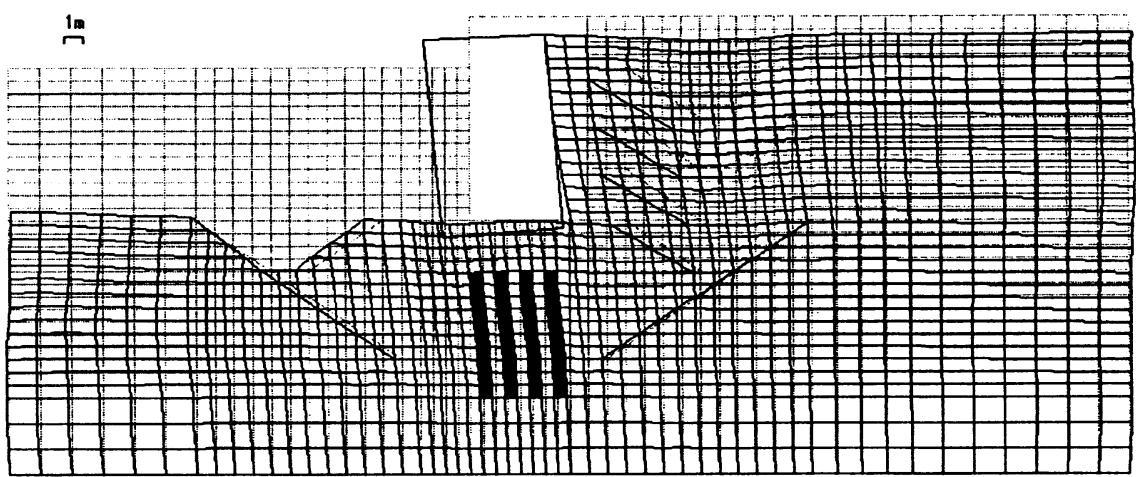

(b) Type B

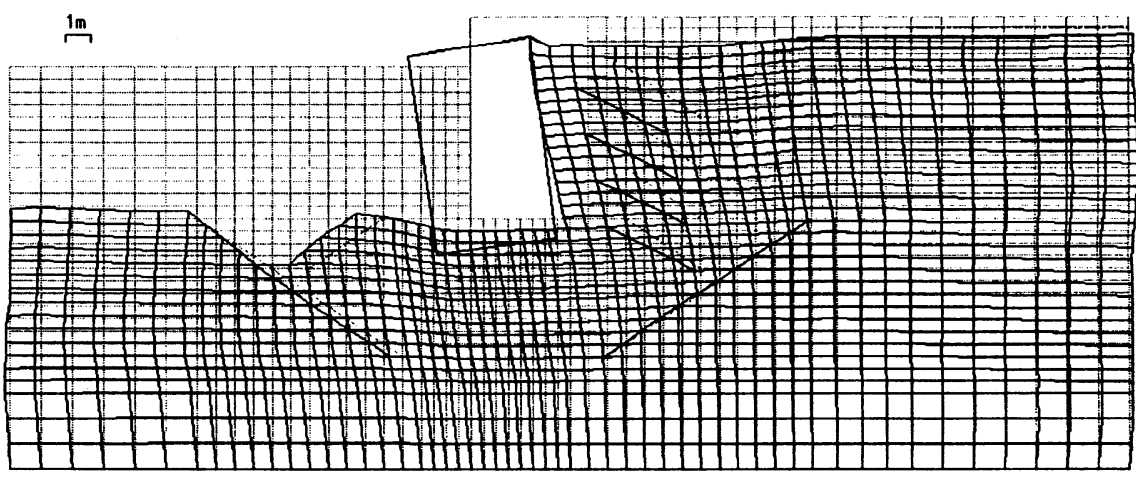

(c) Type $\mathrm{C}$

図一 5 残留变形

表一 1 最終節点変位 (単位 : m)

\begin{tabular}{|c|c|c|c|c|c|c|}
\hline & \multicolumn{2}{|c|}{ Type A } & \multicolumn{2}{c|}{ Type B } & \multicolumn{2}{c|}{ Type C } \\
\cline { 2 - 7 } & $\begin{array}{l}\text { 水平方 } \\
\text { 向変位 }\end{array}$ & $\begin{array}{l}\text { 鈆直方 } \\
\text { 向変位 }\end{array}$ & $\begin{array}{l}\text { 水平方 } \\
\text { 向変位 }\end{array}$ & $\begin{array}{l}\text { 鉛直方 } \\
\text { 向変位 }\end{array}$ & $\begin{array}{l}\text { 水平方 } \\
\text { 向変位 }\end{array}$ & $\begin{array}{c}\text { 鉛直方 } \\
\text { 向変位 }\end{array}$ \\
\hline No.1 & -1.691 & -0.600 & -2.426 & -1.164 & -2.461 & -1.583 \\
\hline No.2 & -0.944 & -0.191 & -1.019 & -0.226 & -1.062 & -0.471 \\
\hline No.3 & -0.933 & -0.047 & -0.845 & -0.217 & -0.831 & -0.438 \\
\hline No.4 & -0.969 & -1.066 & -1.430 & -1.219 & -1.502 & -1.200 \\
\hline No.5 & -0.413 & -0.793 & -0.611 & -0.883 & -0.623 & -0.809 \\
\hline
\end{tabular}

直下に杭基礎を設置し、ケーソンとの接続をしない Type B の場合には、杭基礎を有しない Type C の場合とあまり顥 著な差異は現れないことがわかる。このことは、杭基礎を 用いる際、ケーソン岸壁との接続をしない Type B の場合 にはあまり耐震性が向上しないことを示唆しているものと 考えられる。

図ー 7は、要素 $\mathrm{A} \sim \mathrm{E}$ における過剩間隙水圧比 $p$ の時刻 歴応答を示したものである。なお、過剩間隙水圧比 $p$ は地 盤内部の初期平均有効応力 $\sigma_{m 0}^{\prime}$ に対する地震時応答解析中 の平均有効応力 $\sigma_{m}^{\prime}$ の比を用いて $p=1-\sigma_{m}^{\prime} / \sigma_{m 0}^{\prime}$ で定義さ 
れるものである（ Iai,S. et al.,1992、稲垣・井合、1997）。 これらの図より、杭と杭に挟まれた要素 $\mathrm{A}$ の過剩間隙水 圧比 $p$ にいては、Type A、Type B および Type C とも に最初の 10 秒間は過剩間隙比 $p$ の值が違うものの、ほぼ 同じ傾向を示している。また、ケーソン岸壁直下に杭基礎 を有する Type A およびType B では杭基礎の存在により 杭間の地盤が拘束を受けているため、過剩間隙水圧 $p$ が杭 基礎を有しないType $\mathrm{C}$ の場合に比べて大きくなっている ことがわかる。しかしながら、10 秒前後を過ぎると杭基 礎の存在により、Type A および Type B の過剩間隙比 $p$ の履歴傾向は Type C の過剩間隙比 $p$ が示寸液状化の傾向 とは異なっていることがわかる。要素 B における過剩間 隙比 $p$ の履歴傾向はいずれのタイプも液状化傾向を示して いることがわかる。

一方、埋め立て地盤の深い場所に位置にする要素 Cに
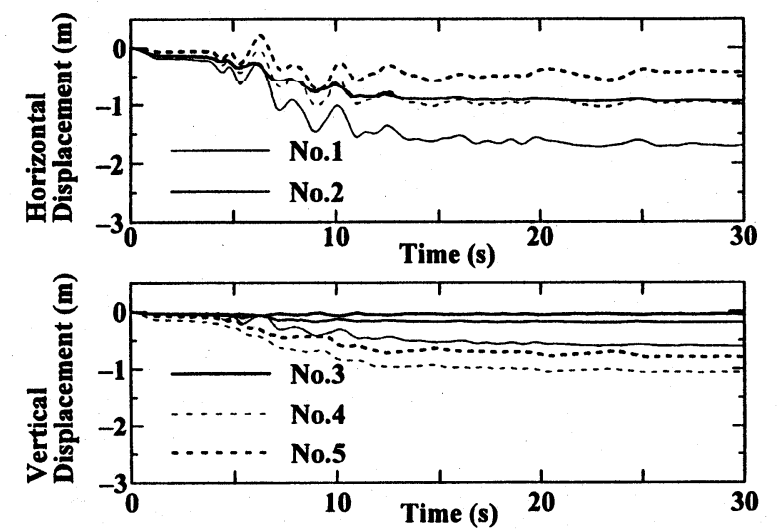

(a) Type $A$
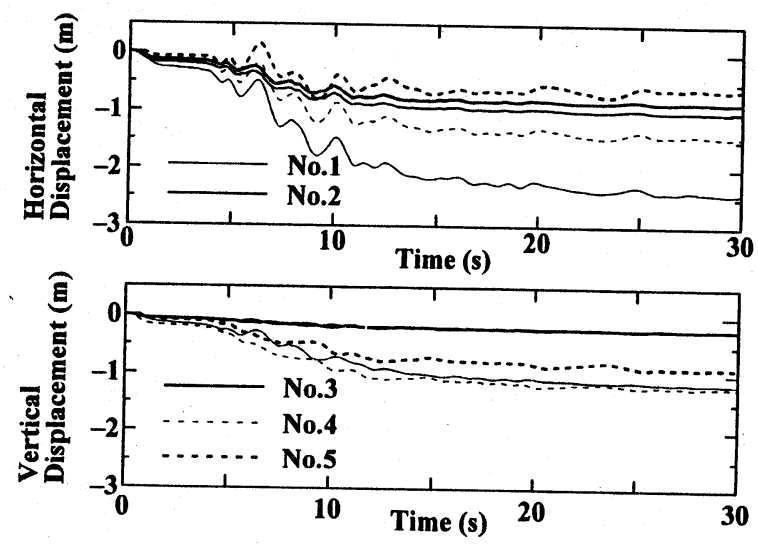

(b) Type B
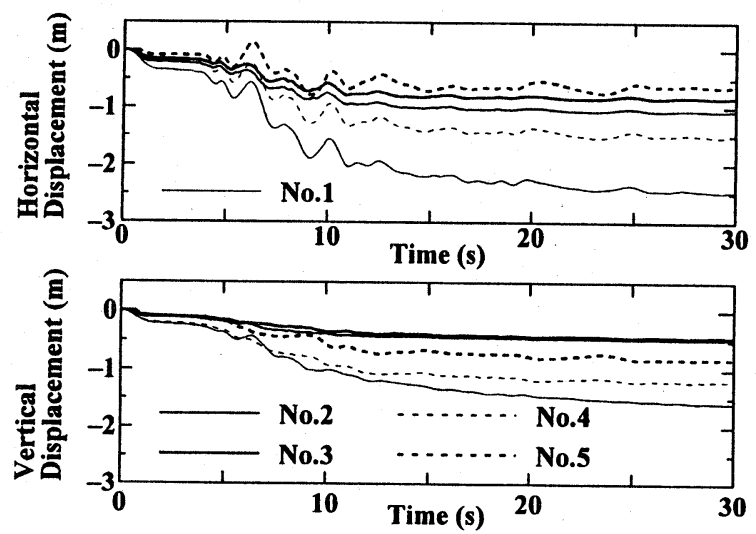

(c) Type C

図一6 節点变位の時刻歴応答
おける過剩間隙比 $p$ はいずれのタイプも最初の 10 秒間は 液状化の傾向を示しているが、図一3に示寸加速度波形か らも明らかなように、主要動が終わりかける 10 秒前後を 過ぎると液状化傾向が無くなっていることがわかる。さら に、ケーソン岸壁から離れた要素 $\mathrm{D}$ および $\mathrm{E}$ の過剩間隙 比 $p$ はいずれのタイプもほぼ同じような液状化傾向を示し ており、ケーソンと杭基礎を接続した Type A の過剩間隙 比 $p$ が最も大きな值となっており、杭基礎を有しない Type Cに比べて杭基礎の存在により Type AおよびType B の 場合には液状化がさらに進むことを示している。このこと は、杭基礎を用いることは、ケーソン岸壁の変位量を押さ えることができるものの、ケーソン岸壁背面の埋め立て地 盤の液状化を一層進めることを示している。したがって、 ケーソン岸壁直下に杭基礎を用いる際には、背面の埋め立 て地盤の液状化対策も併せて行う必要があると考えられる。

次に、上述したケーソン岸壁の直下に杭基礎を設置した 場合の地震時応答結果を踏まえて、図一8の FEM 解析メ ッシュ図に示すように、捨て石マウンド下の置換砂および

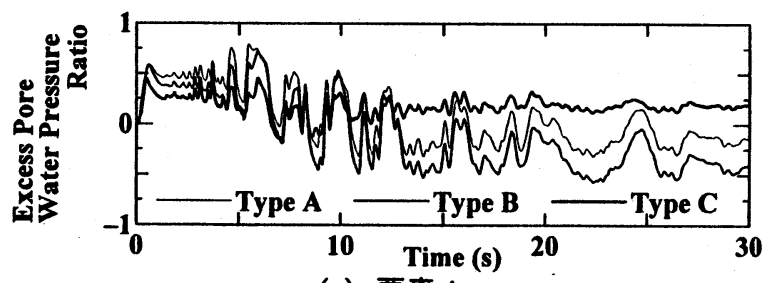

(a) 要素 A

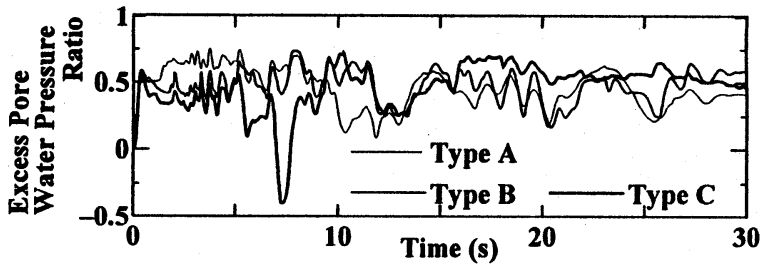

(b) 要素 B

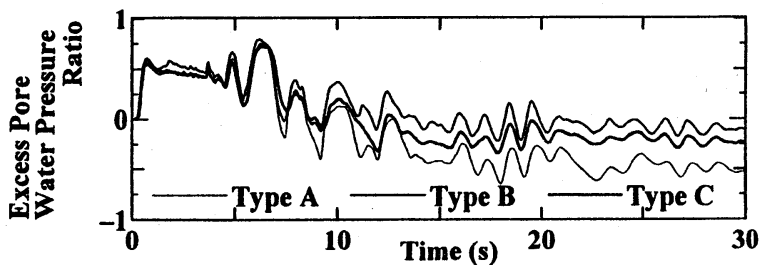

(c) 要素 C

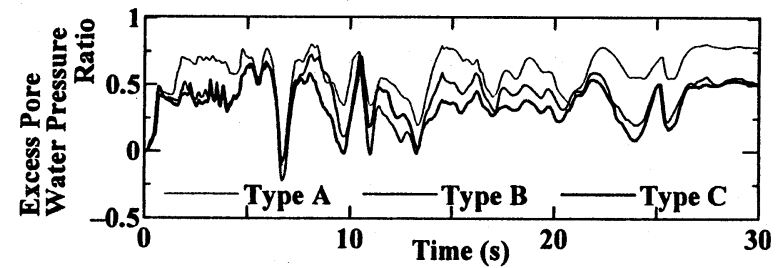

(d) 要素 D

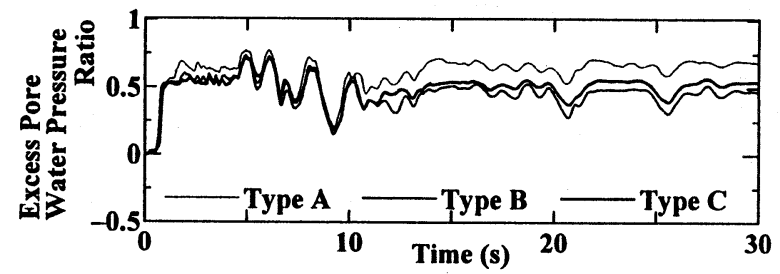

(e) 要素 $\mathrm{E}$

図一 7 過剩間陌水圧比の時刻歴応答 
ケーソン岸壁背面の裏込土を有 しない捨て石マウンドのみを用 いたケーソン岸壁に直接先端拡 底杭基碪を接続した場合の地震 時応答について調べる。お、 本研究ではケーソン岸壁直下に 先端搪底杭およびストレート杭 を用いた場合の応答結果につい て、図ー8中に示すいくつかの 節点および要素の応答量を調べ る。なお、解析対象断面はケー

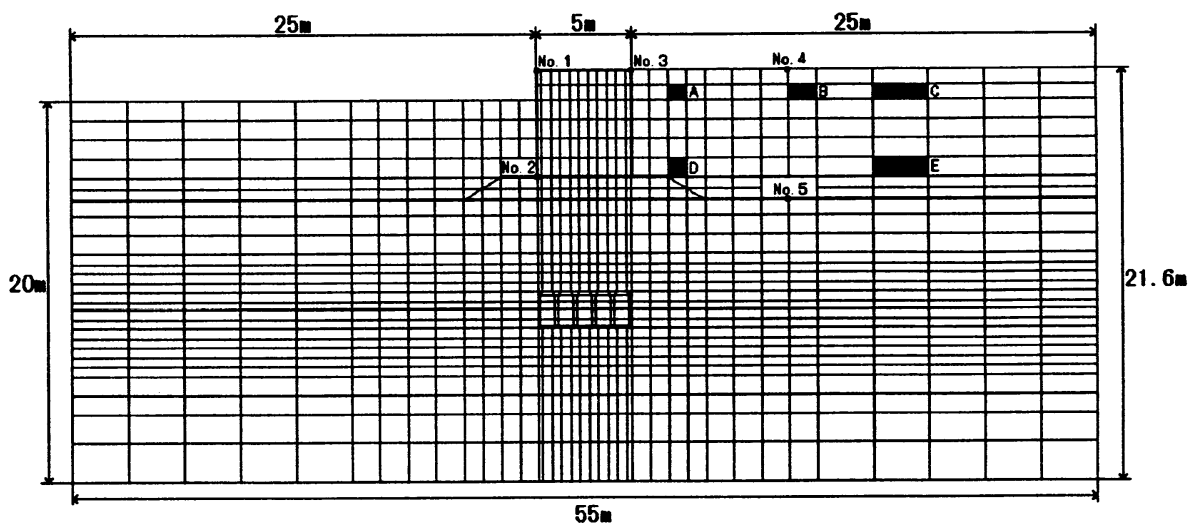
ソン岸壁法線より海側 $25 \mathrm{~m}$ 、陸側 $25 \mathrm{~m}$ 、 海面より-20m の範囲となっている。なお、 地盤条件も図一 4 の場合とは多少異なるも のとなっている。また、入力地震動は図一 3に示す水平動（NS 成分）および上下動 成分に基づいて、解析対象断面の最下層に 換算し直したものを用いた。

図一9は、ケーソン岸壁直下に先端拡底 杭およびストレート杭を用いた場合の地震 時応答解析結果の残留応答変形量を示した ものである。これらの図より、ケーソン直 下の捨て石マウンドおよびマウンド周辺地 盤の変形が大きなものとなっており、先端 拡底杭とストレート杭の違いによる残留変 形量への影響は、ほとんど現れていないこ とがわかる。また、图一5に見られたよう に、ケーソン岸壁背面の埋め立て地盤にお いては、液状化による側方流動が見られて いることがわかる。このため、捨て石マウ ンド直下の置換砂およびケーソン岸壁背 面の裏込土を有しない捨て石マウンドのみを用いたケーソ ン岸壁の施工は、経済性の面からは有利なものとなるが、 従来からのケーソン岸壁施工の場合と同様に、杭基硞を用 いる場合にはケーソン岸壁背面の埋め立て地盤の液状化対 策が必要になるものと考えられる。

図一10 は、先端拡底杭基礎に対する節点 No.1 5 の時 刻歷応答を図示したものである。この図からも明らかなよ うに、杭基礎の存在により、いずれの節点についても、水 平変位量より鉛直変位量が小さな值となっていることがわ かる。また、埋め立て地盤の液状化により他の節点の変位 量に比べて、ケーソン天端の節点 No.1 および No.3 の水 平変位がほぼ司じ程度の大きな值となっており、ケーソン 下端の No.2 のそれよりほぼ 2 倍程度の大きなものとなっ ていることがわかる。さらに、主要動が継続する 10 秒前 後までは、杭基礎の存在によりケーソン背面の埋め立て地 盤の液状化による側方流動に抵抗しているものの、10 秒 前後を過ぎればかなり大きな水平変位を生じていることが わかる。このため、ケーソン背面に位置する節点 No.5 の

図ー8 F EM解析メッシュ図

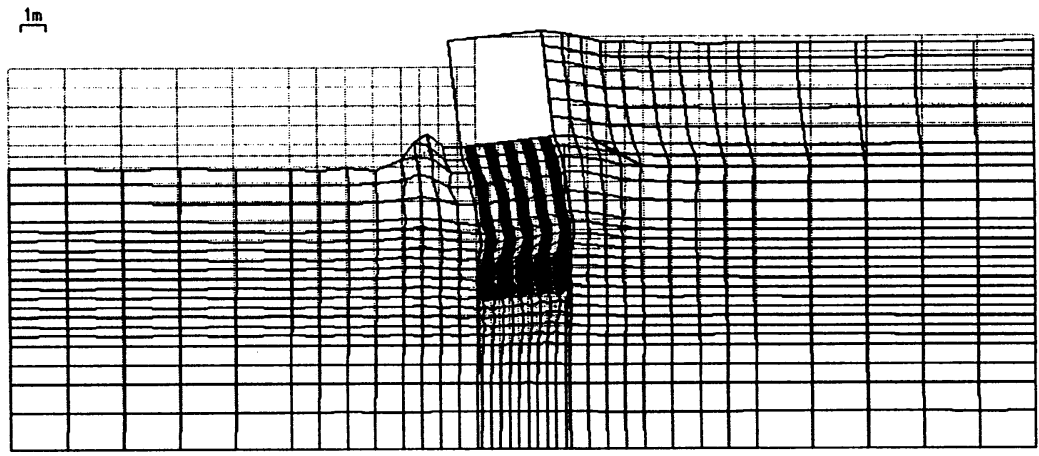

(a) 先端拡底杭

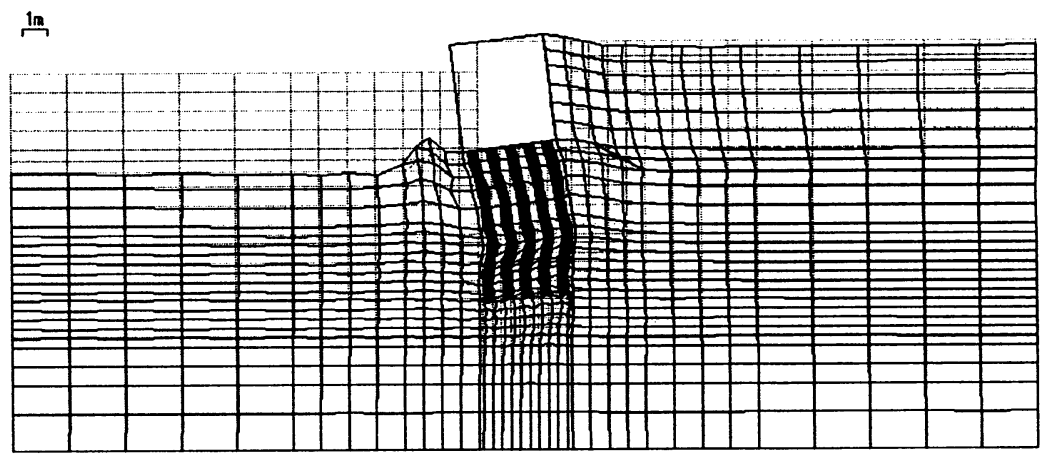

(b) ストレート杭

図一9 残留変形図
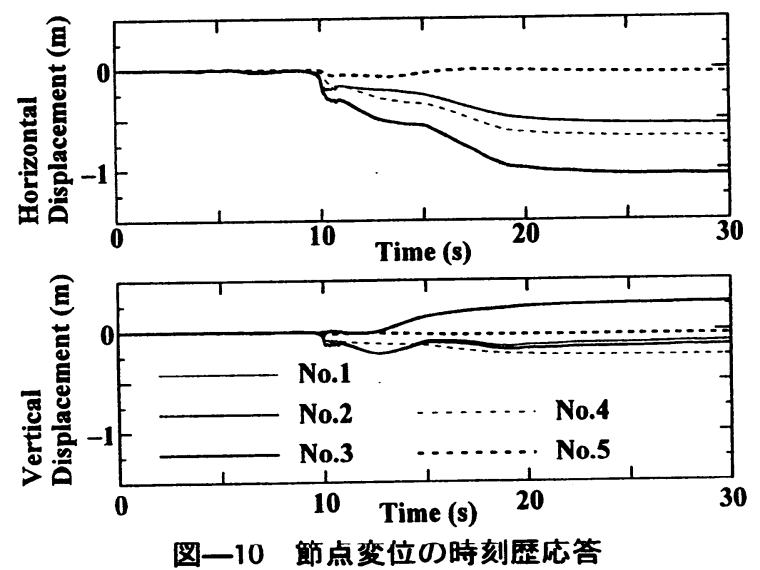

変位量は他の節点に比べて小さな值となっている。

一方、図一11 は図ー8の解析メッシュ図に見られる地 盤内部の要素 $\mathrm{A} \sim \mathrm{E}$ における過剩間隙水圧比 $p$ の時刻歷応 答を示したものである。なお、これら 5 つの要素における 過㮃間隙水圧比 $p$ は主要動が継続する約 10 秒間の液状化 


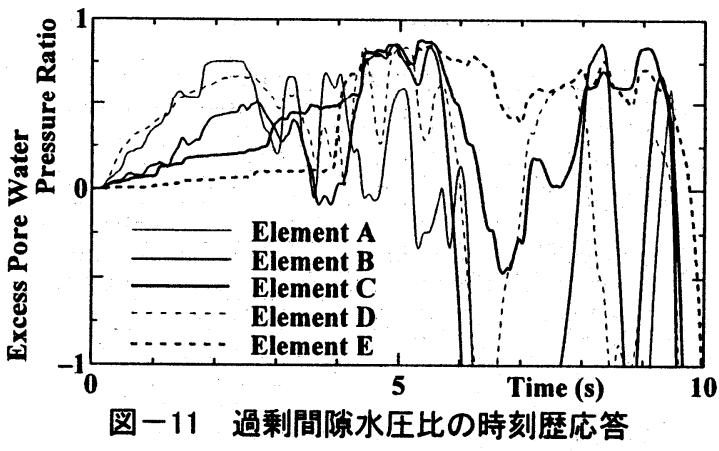

傾向のものとなっており、10 秒以降については過剩間隙 水圧比 $p$ の值が負となっている。この図より、ケーソン岸 壁に近い要素 $\mathrm{A}$ および要素 D の過剩間隙水圧比 $p$ が他の 要素に比べて大きな值へと変動しており、液状化の進行が 早く進んでいることを示している。しかしながら、主要動 が継続している間には、ケーソン岸壁から離れた要素 $\mathbf{C}$ および $\mathrm{E}$ の過剩間隙水圧比 $p$ の方が徐々に液状化傾向を 示していることがわかる。したがって、ケーソン岸壁の直 下に杭基礎を設置すれば、ある程度までは主要動に抵抗し、 背面の埋め立て地盤における液状化を抑える効果を有する ものと考えられる。

\section{4. おわりに}

本研究は、兵庫県南部地震時に記録された加速度波形を 用いて、ケーソン岸壁が杭基礎に直接接続している場合と 杭頭を捨て石層で覆いケーソンとの接続を行わない場合に ついて地震時応答解析を行い、杭基礎の設置がケーソン岸 壁の地震時挙動に及ぼす影響について調べたものである。 また、これらの解析結果を踏まえて、先端拡底杭基礎上の ケーソン岸壁の地震時応答も併せて検討した。

以下に、本研究で得られた主な結論を述べておく。

1. 杭基礎を有しないケーソン岸壁およびその周辺地盤の 地震時応答について、ケーソン岸壁直下の捨て石マウ ンド、置換砂の上部およびケーソン背後の埋め立て地 盤に大きな変形が見られる。

2. ケーソン直下の置換砂内部に杭基礎を設置し、ケーソ ンとの接続をしない場合、ケーソン岸壁の鉛直方向へ の沈下挙動は杭基礎がない場合に比較してかなり抑制 されるものの、地震時変形挙動がケーソン直下、置換 砂の上部およびケーソン背後の埋め立て地盤に限られ るため、ケーソンの海側への傾斜を有効に抑制する効 果は少ない。
3. ケーソン底面に杭基礎を直接接続した場合、ケーソン 岸壁の鉛直および水平方向の変形挙動は、杭基礎を有 しない場合に比べてかなり小さくなり、地震時につい ては非常に有効であると考えられる。しかしながら、 ケーソン背後の埋め立て地盤においてはケーソン下に 設置される杭基礎の有無による影響は少なく、過剩間 隙水圧の上昇により液状化する。

4. ケーソン岸壁㨁下に設置する杭基礎については、先端 拡底杭やストレート杭の違いによる地震時挙動への影 響はあまり顕著なものとなって現れず、ケーソン岸壁 背後の埋め立て地盤においては、慣性力のみならず過 剩間隙水圧の上昇によって生じる側方流動による大き な水平変位が見られる。

ところで、本研究で行ったケーソン岸壁の地震時応答解析 ではストレート杭や先端搪底杭の非線形性は考慮に入れて いないため、今後これらの特性を考慮した地震時時刻歴応 答解析を行う必要があろう。この種の問題については、今 後の検討課題としたい。

最後に、本研究で用いた兵庫県南部地震における加速度 波形記録は、関西地震連絡協議会からの提供を受けたこと を付記するとともに、本研究の一部は文部省科学研究費補 助金基盤研究 $(C)$ (研究代表者 高谷富也、課題番号 09650558）の補助を受けて遂行されたことを付記し、関 係各位に感謝の意を表す。

\section{参考文献}

稲垣紘史・井合 進 (1997)：地震時のケーソン岸壁の変 形照査、海岸工学論文集、第 44 巻、pp.1006-1010.

稲森隆昌ら（1997）：1995 年兵庫県南部地震による港湾 施設等被害報告、港湾技研資料、No.857.

運輸省港湾局（1995）: 阪神・淡路大震災による港湾施設 等被災状況報告書.

社団法人日本港湾協会（1985）: 港湾施設の技術上の基準・ 同解説、p.77.

前野賀彦・児玉洋介（1995）: 既成杭による地中拡底杭、 特願平 7-78405.

前野賀彦・高谷富也・高橋重雄・下迫健一郎（1997）：先 端拡底杭の沿岸域への適用に関する研究、海洋開発論文 集、Vol.13、pp.399-404.

森田年一（1997）: 強震時における重力式岸壁の被災にお よぼす液状化の影響について、第 32 回地盤工学研究発 表会概要、pp.1001-1002.

Iai, S., Matsunaga, Y. and Kameoka, T. (1992): Strain space plasticity model for cyclic mobility, Soils and Foundations, Vol.32, No.2, pp.1-15. 